\title{
ESTIMATION OF THE EFFICIENCY OF APPLYING NANOCOMPOSITES AS ENVIRONMENTALLY SAFE NANOFERTILIZERS TO STIMULATE BIOMETRIC INDICES OF AGRICULTURAL CROPS
}

\author{
M. V. Savchuk ${ }^{1}$, M. F. Starodub ${ }^{1}$, C. Bisio ${ }^{2}$, M. Guidotti ${ }^{3}$, M. M. Lisovyy ${ }^{1}$ \\ ${ }^{1}$ National University of Life and Environmental Sciences of Ukraine, \\ Henerala Rodimtseva, 19 Kiev, Ukraine, 03041 \\ ${ }^{2}$ University of Eastern Piedmont “A. Avogadro”, viale Teresa Michel 11, 15121 Alessandria, Italy \\ ${ }^{3}$ CNR-Institute of Molecular Sciences and Technology, via C. Golgi 19, 20144, Milano, Italy \\ e-mail: TaranMaruna@gmail.com,nfstarodub@gmail.com,matteo@istm.cnr.it, \\ chiara.bisio@uniupo.it,lisova106@ukr.net
}

Received on September 18, 2018

\begin{abstract}
Aim. To estimate the possibilities of applying nanocomposites on the basis of saponite to increase biometric indices of corn hybrid Kharkivsky 340 MV. Methods. laboratory (method of scanning electronic microscopy, method of fluorescence induction of chlorophylls, spectrophotometric method of determining the number of green pigments, methods of determining biometric indices of plants), statistical. Results. This article presents the results of investigating the impact of nanocomposites on biometric indices of corn hybrid Kharkivsky $340 \mathrm{MV}$. It was established that presowing treatment of corn seeds with aqueous solutions of nanocomposites on the basis of saponite in the concentration of $300 \mathrm{mg} / \mathrm{l}$ stimulated growth indices of plants. Presowing soaking of seeds in nanocomposite solutions increased the energy of germination, sprouting and length of hybrid corn seedlings. The action of nanocomposite $\mathrm{Nb}$-saponite (Et) in the concentration of $300 \mathrm{mg} / \mathrm{l}$ leads to the increase in the germination energy by $10.6 \%$, the length of a stem part - 2-fold, root system - by $30.3 \%$ and the laboratory germination of seeds is $100 \%$. The height of a stem of corn plants in the phase of three leaves after presowing treatment of seeds with nanocomposites Saponite $(\mathrm{H}), \mathrm{Nb}$-Saponite $(\mathrm{Cl})$ and $\mathrm{Nb}$-Saponite (Et) in the concentration of $300 \mathrm{mg} / \mathrm{l}$ exceeded the control by $31.7,26.2$ and $42.7 \%$, and the length of the root system increased twice. The action of Saponite (H) and $\mathrm{Nb}$-Saponite $(\mathrm{Cl})$ led to the increase in the number and length of the main roots of corn, and $\mathrm{Nb}-\mathrm{Saponite}(\mathrm{Et})$ stimulated the development of additional roots and formation of root fibrilla. The presowing treatment of corn seeds with the solutions of nanocomposites Saponite $(\mathrm{H}), \mathrm{Nb}$-Saponite $(\mathrm{Cl}), \mathrm{Nb}$-Saponite $(\mathrm{Et})$ in the concentration of $300 \mathrm{mg} / 1$ promoted the increase in the vegetative mass by 35, 27.9 and $56.4 \%$ compared to the control. At the impact of nanocomposites, the area of the leaf plate of plants increased by $20.4 \%$ on average. There was an increase in the sum of chlorophylls $(\mathrm{a}+\mathrm{b})$ in plants, whose seeds were previously treated with nanocomposites $\mathrm{Nb}-\mathrm{Saponite}(\mathrm{Cl})$ and $\mathrm{Nb}$-Saponite (Et) in the concentration of $300 \mathrm{mg} / 1$ by 41.2 and $40.6 \%$ compared to the control. Conclusions. The application of nanocomposites on the basis of saponite in the concentration of $300 \mathrm{mg} / \mathrm{l}$ for presowing treatment of corn seeds of hybrid Kharkivskyi $340 \mathrm{MV}$ promoted the activation of growth indices and improved the process of photosynthesis.
\end{abstract}

Keywords: nanocomposites, corn, seeds, growth processes, physiological parameters, stem, root system.

DOI: 10.15407 /agrisp5.02.064

\section{INTRODUCTION}

At present Ukraine's agrarian sector needs new environmentally safe and efficient preparations for treatment of agricultural crops, which would enhance seed-

(C) M. V. SAVCHUK, M. F. STARODUB, C. BISIO, M. GUIDOTTI, M. M. LISOVYI, 2018

ing qualities, stimulate growth indices and performance and protect a plant from unfavorable factors, but would not pollute the environment.

Traditionally salts of heavy metals and chelate compounds are used as microfertilizers in Ukraine and in the world, due to which there is accumulation of salts 


\section{ESTIMATION OF THE EFFICIENCY OF APPLYING NANOCOMPOSITES}

of heavy metals in the environment and aggravation of its ecological condition [1]. Thus, the use of a new kind of microfertilizers, based on nanoparticles, has found wider application.

A promising direction of using nanoparticles is deemed to be their application in very low concentrations with the purpose of obtaining environmentally pure products [2].

The main aspect of nanotechnology development in plant cultivation is the production of new kinds of microfertilizers based on nanomaterials. Among various nanomaterials, considerable popularity was noted for nanocomposites which combine nanoparticles, located in the structure-forming material - a matrix [3]. Nanocomposites on the basis of saponite are promising meliorants of complex action, which promote greater harvest and increase the accumulation of resources of available nutrients of nitrogen, phosphorus, potassium, and also calcium and magnesium in soil [4-5].

Nanoparticles of oxides of metals enhance the efficiency of processes in plants and participate in the formation of microelement balance [1]. Ukrainian and foreign scientists demonstrated in their works that the use of nanopreparations, based on nanoparticles of oxides of metals led to enhancing of photosynthetic processes, growth indices, and performance of agricultural crops [6-11].

Some concentrations of iron nanoparticles may increase the performance of cereal crops in the range from 10 to $40 \%$. It was established that presowing treatment of rapeseed using iron nanopowders led to the development of the root system, the increase in photosynthetic surface and water-retaining capability of leaves, their resistance to diseases and, as a result, to improving the performance and quality of products [12]. The improvement of photosynthetic processes in legumes and the increase in germination and energy of sprouting was observed while using nanocomposites. Nanomaterials found their application in after-harvest processing of sunflower, tobacco, potato, apples [5, 13].

The aim of our study was to estimate the possibilities of applying nanocomposites on the basis of saponite to increase biometric indices of corn hybrid Kharkivsky $340 \mathrm{MV}$.

\section{MATERIALS AND METHODS}

The study was conducted in the laboratory of biosensorics of the National University of Life and Environmental Sciences of Ukraine. In 2012-2017 there were physical-chemical and biological studies on 3 samples of nanocomposites based on synthetically created minerals - saponites, synthesized at the CNR-Institute of Molecular Technologies, Milan, Italy. The nanomaterials were provided in the framework of NATO project No. NUKR.SFP 984481.

Nanominerals under study:

1). nanocomposite Saponite $(\mathrm{H})$;

2). nanocomposite $\mathrm{Nb}$-Saponite (Et);

3). nanocomposite $\mathrm{Nb}$-Saponite $(\mathrm{Cl})$.

The microstructure of nanocomposites was studied by the method of scanning electronic microscopy (SEM) using Leo 1550 Gemini SEM (Sweden), at the voltage in the range of $10-20 \mathrm{kV}$ and the standard diaphragm value of $30 \mu \mathrm{m}$. The samples of Saponite (H) had a somewhat triangular form which reflected their tetragonal structure. In conditions of dissolving, they agglomerated into larger spatial formations, but remained porous, with the size of pores at the level of $100 \mathrm{~nm}$, which demonstrated a considerable area of their active surface. The samples of Nb-Saponite (Et) of triangular form were 20-30 nm thick. Nanocomposites $\mathrm{Nb}$-Saponite $(\mathrm{Cl})$ were over $30 \mathrm{~nm}$, but similarly to the latter, they agglomerated with the formation of separate flakes. Previous works demonstrated and proved that nanocomposites on the basis of saponites are environmentally safe substances [14-16].

The study on the impact of nanocomposites on the condition of plants was conducted using hybrid corn Kharkivskyi $340 \mathrm{MV}$. The scheme of studies envisaged different variants of treating seeds. The treatment was conducted by soaking corn seeds in nanocomposite solutions for $5 \mathrm{~h}$ as per $3 \mathrm{l} / \mathrm{t}$ respectively: control - seeds treated with water; variants $1,2,3,4$ - seeds treated with nanocomposite Saponite $(\mathrm{H})$ in the concentration of 150,$300 ; 450 ; 600 \mathrm{mg} / \mathrm{l}$ respectively; variants 5,6 , $7,8-\mathrm{Nb}$-Saponite $(\mathrm{Cl})$ in the concentration of 150 ; $300 ; 450 ; 600 \mathrm{mg} / 1$ respectively; variants $9,10,11,12$ $\mathrm{Nb}$-Saponite $(\mathrm{Et})$ in the concentration of $150 ; 300 ; 450$; $600 \mathrm{mg} / 1$ respectively.

Laboratory experiments on the impact of nanocomposites on corn were conducted on the basis of the laboratory of biosafety, the chair of molecular biology, microbiology and biosafety of the National University of Life and Environmental Sciences of Ukraine. A current method according to DSTU 4138-2002 was used to determine the germination of corn seeds. The energy of seed germination - the capability of its fast and thick germination - was determined together with laboratory germination $[17,18]$. 


\section{SAVCHUK et al.}

The vegetation experiments were conducted in phytoclimatic chambers «Silver box evolution» (Ukraine) of the laboratory of biosensorics of the chair of molecular biology, microbiology and biosafety (2016-2017). Previously treated corn seeds of hybrid Kharkivskyi $340 \mathrm{MV}$ were sown in a phytotron with plastic vials of 2-5 1, containing clay pellets as the backing mixture. Each vial had 10-12 plants, grown in 3-4 repeats. The plants were grown at $18-25{ }^{\circ} \mathrm{C}$, illuminated with SHPTS Gro Lux lamp, the dark interval lasted $9 \mathrm{~h}$, the light interval $-15 \mathrm{~h}$. The temperature was maintained at the level of $20-25 / 18-20{ }^{\circ} \mathrm{C}$ (day/night).

The length of sprouts and roots was estimated with a ruler for each plant, which had a sprout and a root. The mass of the aboveground and underground parts was determined using digital analytical scales Ohaus Pioneer (USA). The area of the leaf apparatus was determined by its length, width, and transferring coefficient which was 0.67 for crops with the oblong form of leaves. The area was calculated by the following formula:

$$
\mathrm{A}=\mathrm{L} \cdot \mathrm{W} \cdot \mathrm{C},
$$

where $\mathrm{A}$ - area of the leaf, sq.cm; C - transferring coefficient (0.67); L - length of the leaf, $\mathrm{cm}$; W - width of the leaf [19].

To determine chlorophylls $a$ and $b$, fresh leaves of corn were cut with scissors in small pieces and the sample of $500 \mathrm{mg}$ was taken. The sample was placed into a porcelain mortar and ground with $5 \mathrm{ml}$ of the solvent ( $96 \%$ of ethyl alcohol) and silica sand. The obtained suspension was filtered into a dry measuring tube, the filter was washed with the solvent until complete removal of pigments. The obtained extract was poured into a tube of $50 \mathrm{ml}$ with the addition of ethyl alcohol up to the mark, mixed well and passed through the spectrophotometer Unico 1205 (USA) at corresponding wavelengths. The concentration of pigments was calculated by the equations:

$$
\begin{aligned}
& \mathrm{C}_{\text {chl. a }}=13.70 \mathrm{D}_{665}-5.76 \mathrm{D}_{649} ; \\
& \mathrm{C}_{\text {chl. b }}=25.80 \mathrm{D}_{649}-7.60 \mathrm{D}_{665} ; \\
& \mathrm{C}_{\text {chl. a }+ \text { chl. b }}=6.10 \mathrm{D}_{665}+20.04 \mathrm{D}_{649},
\end{aligned}
$$

where $\mathrm{C}_{\text {chl. a }}, \mathrm{C}_{\text {chl. b }}, \mathrm{C}_{\text {chl. a }+ \text { chl. b. }}$ - the concentrations of chlorophylls $a, b$, and their sum, respectively, $\mathrm{mg} / 1$ [20].

The content of pigments (A) in the plant material, $\mathrm{mg} / \mathrm{g}$ of raw mass, was calculated by the equation:

$$
\mathrm{A}=(\mathrm{C} \cdot \mathrm{V}) /(\mathrm{W} \cdot 1000) \text {, }
$$

where $\mathrm{C}$ - concentration of pigments, $\mathrm{V}$ - volume of the extract, $\mathrm{ml}(25 \mathrm{ml}), \mathrm{W}$ - weighed quantity of plant material, g (0.2 g) [21].

The kinetics of changes in fluorescence induction of chlorophyll (FIC) was determined by a portable device, chronoflourometer «Floratest» (Ukraine), in the laboratory of biosensorics of the chair of molecular biology, microbiology and biosafety at the National University of Life and Environmental Sciences of Ukraine. The adaptation of corn leaves to darkness was conducted for $5 \mathrm{~min}$. The FIC parameters of plants were measured in the phase of three leaves in the central part of the

Table 1. The impact of nanocomposites on sowing qualities of corn seeds of hybrid Kharkivskyi 340 MV

\begin{tabular}{l|c|c|c}
\hline \multicolumn{1}{c|}{ Variants } & $\begin{array}{c}\text { Concentration in aqueous } \\
\text { medium, mg/1 }\end{array}$ & $\begin{array}{c}\text { Energy } \\
\text { of seed germination, \% }\end{array}$ & $\begin{array}{c}\text { Laboratory germination } \\
\text { of seeds, \% }\end{array}$ \\
\hline Control & - & $82.67 \pm 1.73$ & $96.00 \pm 1.13$ \\
Nanocomposite Saponite (H) & 150 & $87.33 \pm 1.73$ & $96.67 \pm 0.65$ \\
& 300 & $91.33 \pm 0.65$ & $97.33 \pm 0.65$ \\
Nanocomposite Nb-Saponite (Cl) & 450 & $90.00 \pm 1.13$ & $96.67 \pm 0.65$ \\
& 600 & $91.33 \pm 0.65$ & $97.33 \pm 1.73$ \\
Nanocomposite Nb-Saponite (Et) & 150 & $90.67 \pm 0.65$ & $99.33 \pm 0.65$ \\
& 300 & $91.78 \pm 0.22$ & $98.67 \pm 0.65$ \\
& 450 & $92.67 \pm 0.65$ & $98.45 \pm 0.65$ \\
& 600 & $92.67 \pm 0.65$ & $97.33 \pm 0.65$ \\
& 400 & $93.33 \pm 1.31$ & $100.00 \pm 0.00$ \\
\end{tabular}




\section{ESTIMATION OF THE EFFICIENCY OF APPLYING NANOCOMPOSITES}

formed leaf plate. The intensity of chlorophyll fluorescence was measured in three repeats for each variety, in 90 points with the time interval from $3 \mu \mathrm{s}$ to $300 \mathrm{~s}$ $[22,23]$ and then transferred into relative units. Microsoft Excel was used to build induction curves using the points and to analyze amplitude and temporal parameters of their separate phases [24].

\section{RESULTS AND DISCUSSION}

Impact of newly synthesized nanocomposites on sowing qualities of corn seeds. High quality sowing material was used to obtain good harvest of agricultural crops. It is believed that harvest may be increased by $20-25 \%$ if more quality seeds are used [18]. Germination is referred to the main indices, which characterize sowing qualities of seeds. It was proven that only while sowing seeds with high germination properties, established by the standard, one may obtain fast and thick sprouts and more productive plants. In other words, germination is a measure of viability of the sowing material. It is determined both in laboratory (optimal) and field conditions. As a rule, laboratory germination exceeds the one in the field. Scientists and specialists traditionally believe that the lower the laboratory germination of seeds is, the lower harvest is, obtained by sowing such seeds. The energy of seed germination is determined along with the laboratory germination and is believed to be its capability of fast and thick germination. It is natural that seeds, which are the first to germinate, have higher vital power and form more productive descendants than the ones, which germinate later, thus, the biological value of germination energy is very important [25-27].

The presowing treatment of seeds with aqueous solutions of nanocomposites on the basis of saponite in laboratory experiments promoted the increase in germination energy and sprouting for corn seeds (Table 1).

The presowing treatment of corn seeds of hybrid Kharkivskyi 340 MV with nanocomposites demonstrated positive results in all the investigated concentrations. With nanopreparations, the germination energy exceeded the control by $8.93 \%$ on average. The maximal increase in the germination energy by $10.66 \%$ compared to the control was observed at the concentration of nanocomposite Nb-Saponite (Et) $300 \mathrm{mg} / \mathrm{l}$. At the action of nanocomposites Saponite $(\mathrm{H})$ and $\mathrm{Nb}$-Saponite $(\mathrm{Cl})$ in the concentration of $300 \mathrm{mg} / \mathrm{l}$, the germination energy increased by 8.7 and $9.3 \%$ respectively compared to the control.

When nanocomposites on the basis of saponite were used, the laboratory germination of corn seeds exceeded the control by $1.9 \%$ on average. During the application of nanocomposite $\mathrm{Nb}$-Saponite $(\mathrm{Et})$ in the concentration of $300 \mathrm{mg} / \mathrm{l}$, the value of this index was $100 \%$ which demonstrates a high stimulating effect of this nanocomposite. Seed germination after presowing soaking in aqueous solutions of nanocomposites Saponite $(\mathrm{H})$ and $\mathrm{Nb}$-Saponite $(\mathrm{Cl})$ in the concentration of

Table 2. The morphophysiological indices of corn seeds of hybrid Kharkivskyi $340 \mathrm{MV}$ after treatment with nanocomposites based on saponite

\begin{tabular}{|c|c|c|c|}
\hline Variants & $\begin{array}{l}\text { Concentration in aqueous } \\
\text { medium, mg/l }\end{array}$ & $\begin{array}{l}\text { Length of root part } \\
\text { of seedlings, mm }\end{array}$ & $\begin{array}{l}\text { Length of stem part } \\
\text { of seedlings, mm }\end{array}$ \\
\hline Control & - & $79.33 \pm 4.57$ & $18.00 \pm 1.13$ \\
\hline \multirow[t]{4}{*}{ Nanocomposite Saponite (H) } & 150 & $80.67 \pm 5.81$ & $17.67 \pm 2.36$ \\
\hline & 300 & $82.33 \pm 8.49$ & $19.67 \pm 0.65$ \\
\hline & 450 & $81.00 \pm 8.98$ & $19.67 \pm 1.73$ \\
\hline & 600 & $81.33 \pm 3.64$ & $19.33 \pm 0.65$ \\
\hline \multirow[t]{4}{*}{ Nanocomposite $\mathrm{Nb}$-Saponite $(\mathrm{Cl})$} & 150 & $79.33 \pm 1.73$ & $21.00 \pm 1.73$ \\
\hline & 300 & $84.00 \pm 1.73$ & $24.00 \pm 1.13$ \\
\hline & 450 & $83.67 \pm 1.73$ & $23.67 \pm 0.65$ \\
\hline & 600 & $83.33 \pm 1.31$ & $24.67 \pm 0.65$ \\
\hline \multirow[t]{4}{*}{ Nanocomposite Nb-Saponite (Et) } & 150 & $89.33 \pm 4.57$ & $32.00 \pm 1.13$ \\
\hline & 300 & $103.33 \pm 2.85$ & $38.00 \pm 2.26$ \\
\hline & 450 & $102.00 \pm 2.26$ & $37.67 \pm 0.65$ \\
\hline & 600 & $103.33 \pm 2.36$ & $38.00 \pm 1.96$ \\
\hline
\end{tabular}




\section{SAVCHUK et al.}
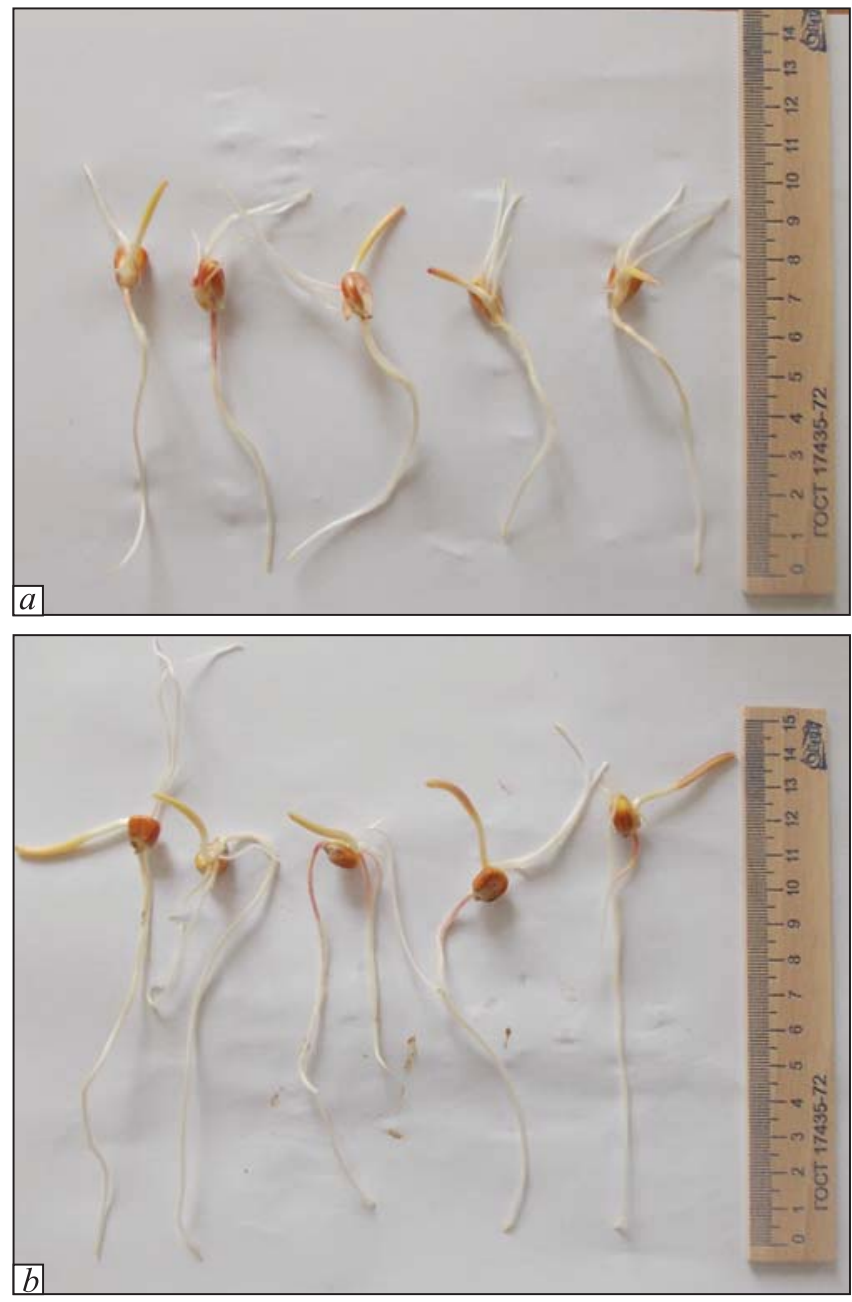

Fig. 1. The development of plants on the seventh day of germination: a) control, b) treated with nanocomposite $\mathrm{Nb}$ Saponite (Et) in the concentration of $300 \mathrm{mg} / \mathrm{l}$

$300 \mathrm{mg} / \mathrm{l}$ was 97.3 and $99.3 \%$ respectively whereas it was $96 \%$ for the control.

The results of studies on the impact of nanocomposites on morphophysiological properties of corn seeds demonstrated that newly synthesized nanomaterials improved growth indices of stem and root parts of sprouts (Table 2). Niobium-containing nanocomposites on the basis of saponite demonstrated a stronger stimulating effect regarding the length of the stem and root parts of corn seed sprouts compared to nanocomposite Saponite (H.) At the action of nanocomposite Saponite $(\mathrm{H})$ the length of the root and stem parts of a corn seedling increased by 2.5 and $6.0 \%$ on average respectively compared to the control. As for nanocomposite $\mathrm{Nb}$-Saponite $(\mathrm{Cl})$, the value of the stem part increased by $29.6 \%$ on average compared to the control, and at the action of nanocomposite $\mathrm{Nb}$-Saponite (Et) the average value of the stem part increased twice com- pared to the control. At the action of nanocomposites $\mathrm{Nb}$-Saponite $(\mathrm{Cl})$ and $\mathrm{Nb}$-Saponite (Et), the root part of corn seedlings increased by $4.1 \%$ and $25.38 \%$ on average respectively compared to the control.

The data, presented in Table 2, demonstrate that the best growth indices of the stem part of corn seedlings were observed for the use of nanocomposite $\mathrm{Nb}$-Saponite (Et) in the concentration of $300 \mathrm{mg} / \mathrm{l}$, when the length of the stem part of corn seedlings increased twice on average compared to the control. At the action of nanocomposite $\mathrm{Nb}$-Saponite (Et) in the concentration of $300 \mathrm{mg} / \mathrm{l}$ the root part of corn seedlings increased by $30.25 \%$ compared to the control (Fig. 1).

The study on the impact of nanocomposites on morphological indices of corn. Further studies required planting corn seedlings into a phytoclimatic chamber. The plants were grown at $18-25^{\circ} \mathrm{C}$, the dark interval lasted $9 \mathrm{~h}$, the light interval $-15 \mathrm{~h}$. The temperature was maintained at the level of $20-25 / 18-20{ }^{\circ} \mathrm{C}$ (day/ night). The investigation of masses and morphological indices of plants was conducted in the phase of three leaves.

The phase of 3-5 leaves is remarkable for corn plants during the vegetation period, as this is when plants are most sensitive to being overrun with weeds and to unfavorable weather conditions. The data in Table 3 demonstrates that the use of nanocomposites based on saponite improved growth indices of plants.

The indices of stem height and length of root system for corn plants in the control variant were $18.73 \mathrm{~cm}$ and $12.27 \mathrm{~cm}$ on average respectively. With the use of nanocomposites Saponite $(\mathrm{H}), \mathrm{Nb}$-Saponite $(\mathrm{Cl})$ and $\mathrm{Nb}$-Saponite (Et) in the concentration of $300 \mathrm{mg} / \mathrm{l}$, the index of stem height increased by $31.7 \%, 26.2 \%$ and $42.7 \%$ respectively compared to the control (Fig. 2).

With the use of nanocomposites Saponite $(\mathrm{H}), \mathrm{Nb}-$ Saponite $(\mathrm{Cl})$ and $\mathrm{Nb}$-Saponite $(\mathrm{Et})$ in the concentration of $300 \mathrm{mg} / \mathrm{l}$ the length of the root system increased twice on average compared to the control (Table 3).

While studying the impact of nanocomposites of the root system of plants it was observed that the action of nanocomposites Saponite $(\mathrm{H})$ and $\mathrm{Nb}$-Saponite $(\mathrm{Cl})$ led to the increase in the number and length of the main roots of corn, and nanocomposite Nb-Saponite (Et) stimulated the development of additional roots and formation of root fibrilla (Fig. 3).

This impact demonstrates the improvement in the intake of minerals, water and nutrients to plants, as the function of absorbing water and mineral substances, 


\section{ESTIMATION OF THE EFFICIENCY OF APPLYING NANOCOMPOSITES}

dissolved therein, is the most important function of roots and root fibrilla, transporting nutrients to the root, and further on to the plant organism.

The analysis of the mass of control and experimental plants demonstrated (Fig. 4) that all the investigated nanocomposites promoted the accumulation of vegetative mass. The use of nanocomposites Saponite $(\mathrm{H})$, $\mathrm{Nb}$-Saponite $(\mathrm{Cl}), \mathrm{Nb}$-Saponite $(\mathrm{Et})$ increased the mass of plants at the concentration of $300 \mathrm{mg} / \mathrm{ml}$ by 35,28 and $56.43 \%$ respectively compared to the control.

Table 4 demonstrates that at the action of nanocomposites Saponite $(\mathrm{H}), \mathrm{Nb}$-Saponite $(\mathrm{Cl})$ and $\mathrm{Nb}$-Saponite (Et) the mass of the aboveground part of corn increased by 25,10 and $36.25 \%$ on average respectively compared to the control.

At the action of nanocomposites Saponite $(\mathrm{H}), \mathrm{Nb}-$ Saponite $(\mathrm{Cl})$, and $\mathrm{Nb}$-Saponite (Et) the mass of the root system of corn plants exceeded control values by $16.3,20.5$ and $39.7 \%$ on average respectively.

Nanocomposite $\mathrm{Nb}$-Saponite (Et) showed the best results in promoting mass accumulation of the aboveground and underground parts of corn plants. While using the nanocomposite material in the concentration of $300 \mathrm{mg} / \mathrm{l}$, the mass of the aboveground part of corn plants increased by $57.5 \%$ compared to the control, and the mass of the root system increased by $55 \%$.

The study on the impact of nanocomposites on photosynthetic apparatus of corn plants. The process of photosynthesis in plants is one of the most relevant indi-

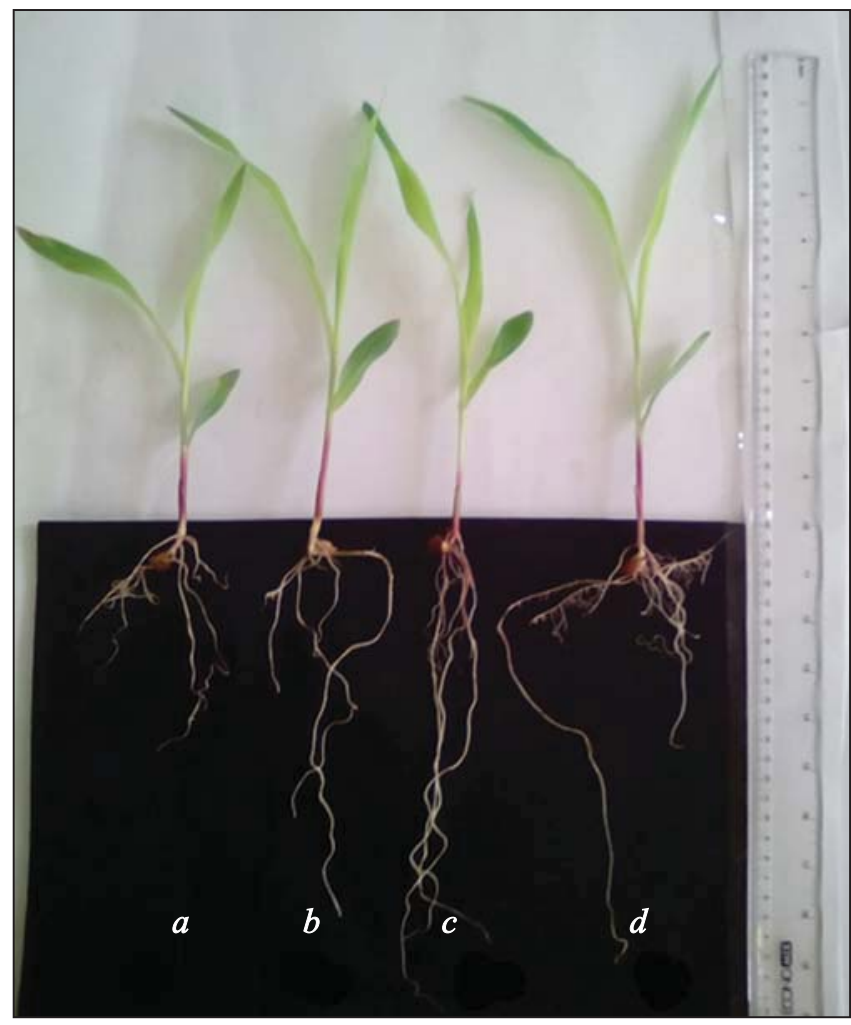

Fig. 2. Corn plants in the phase of three leaves: $a$ - control; $b$ - nanocomposite Saponite $(\mathrm{H})-300 \mathrm{mg} / \mathrm{l} ; c$ - nanocomposite $\mathrm{Nb}$-Saponite $(\mathrm{Cl})-300 \mathrm{mg} / \mathrm{l} ; d$ - nanocomposite $\mathrm{Nb}$ Saponite (Et) - $300 \mathrm{mg} / 1$

ces of plant physiology. Experimental studies of many scientists proved that the photosynthetic performance of plants depends on the area of assimilation surface,

Table 3. The morphological indices of corn plants of hybrid Kharkivskyi $340 \mathrm{MV}$ in the phase of three leaves at the effect of nanocomposites

\begin{tabular}{l|c|c|c}
\hline \multicolumn{1}{c|}{ Variants } & $\begin{array}{c}\text { Concentration in aqueous } \\
\text { medium, mg/1 }\end{array}$ & $\begin{array}{c}\text { Height of stem, } \\
\mathrm{cm}\end{array}$ & $\begin{array}{c}\text { Length of root system, } \\
\mathrm{cm}\end{array}$ \\
\hline Control & - & $18.73 \pm 0.28$ & $12.27 \pm 0.43$ \\
Nanocomposite Saponite (H) & 150 & $18.90 \pm 0.39$ & $14.63 \pm 1.2$ \\
& 300 & $24.67 \pm 1.42$ & $23.43 \pm 0.73$ \\
& 450 & $24.07 \pm 2.33$ & $22.73 \pm 1.41$ \\
Nanocomposite Nb-Saponite (Cl) & 600 & $24.30 \pm 2.10$ & $19.83 \pm 0.77$ \\
& 150 & $20.50 \pm 0.79$ & $23.50 \pm 0.41$ \\
Nanocomposite Nb-Saponite (Et) & 300 & $23.63 \pm 0.36$ & $23.07 \pm 0.52$ \\
& 450 & $23.03 \pm 0.57$ & $23.30 \pm 0.52$ \\
& 600 & $21.83 \pm 0.47$ & $23.20 \pm 0.23$ \\
& 150 & $26.73 \pm 0.56$ & $25.90 \pm 0.52$ \\
\hline
\end{tabular}


SAVCHUK et al.

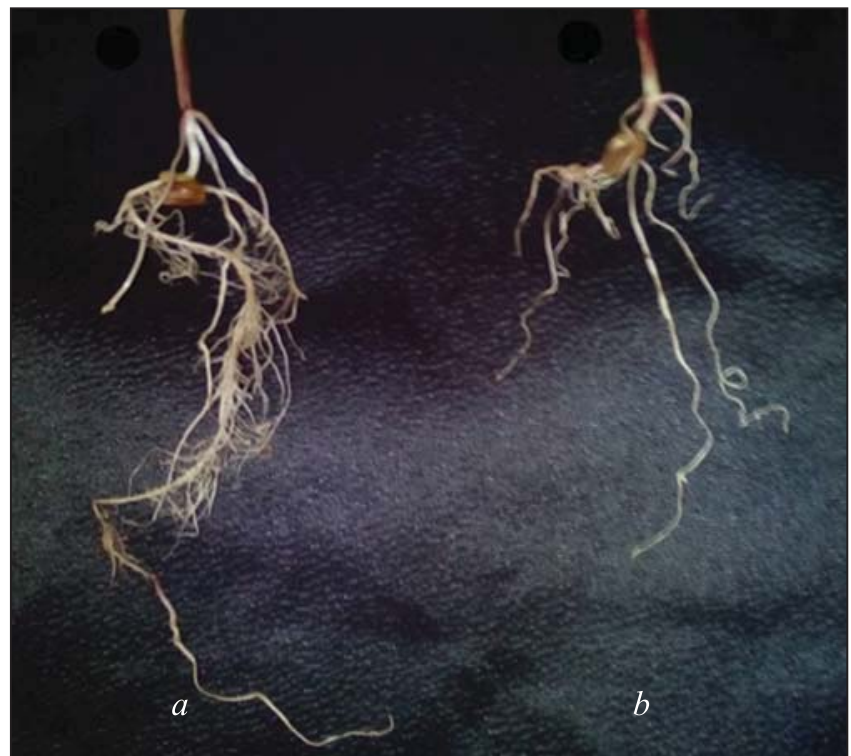

Fig. 3. The impact of nanocomposites on the development of the root system of plants in the phase of three leaves: $a$ - nanocomposite $\mathrm{Nb}$-Saponite (Et) $-300 \mathrm{mg} / \mathrm{l} ; b$ - control

the intensity of photosynthesis, daily gain in vegetative mass, etc. [28]. The area of a leaf plate is considered to be one of the main indices which characterizes the condition of plantings from the standpoint of their photosynthetic activity [29]. It was established that the larger area of leaf surface is, the faster the accumulation of organic matter by agricultural crops is, which conditions the increase in performance per one unit of planted area [12, 30].

It was established that the presowing treatment of seeds with aqueous solutions of nanocomposites, based on saponite, increased the area of a leaf plate by $20.4 \%$ on average compared to the control. The highest increase in the area of a corn leaf plate was noted at the impact of nanocomposite $\mathrm{Nb}$-Saponite (Et) in the concentration of $300 \mathrm{mg} / 1$ - this index increased by $44.5 \%$. At the impact of nanocomposites Saponite $(\mathrm{H})$ and $\mathrm{Nb}$-Saponite $(\mathrm{Cl})$ this index exceeded the control by 2 and $25 \%$ on average respectively (Fig. 5).

The performance of photosynthesis processes is closely related to chlorophyll of leaves which plays the role of a sensibilizator, i.e. a substance, absorbing light [31]. Chlorophylls $a$ and $b$ are relevant photosynthesizing pigments of higher plants, which are Mg-containing porphyrins, most of them are included into the composition of light-collecting complexes, ensure absorption and transfer of light energy to reaction centers where photosynthetic reactions take place [32]. With the participation of pigments, the energy of light quantum is transformed into macrocompounds, which are further used for the synthesis of organic compounds in a plant.

The spectrophotometric analysis revealed that during the phase of three leaves the chlorophyll content in corn plants of hybrid Kharkivskyi $340 \mathrm{MV}$, which was previously treated with nanocomposites, increased by $21.8 \%$ compared to the control. The same regularity was also revealed for chlorophyll $b$, and the number of chlorophylls in plant leaves increased by $4.3 \%$ on average compared to the control.

After the previous treatment of corn seeds with nanocomposites Saponite $(\mathrm{H}) \mathrm{Nb}$-Saponite $(\mathrm{Cl})$ and $\mathrm{Nb}$ Saponite (Et), the content of chlorophylls $a$ and $b$ increased by 15.5 and $2 \%, 28.9$ and $13 \%$, and 26.7 and $4.3 \%$ on average compared to the control.

The highest content of chlorophyll $a$ was noted in hybrid corn leaves, whose seeds were treated with solvents of nanocomposites $\mathrm{Nb}$-Saponite $(\mathrm{Et})$ and $\mathrm{Nb}$ Saponite $(\mathrm{Cl})$ in the concentration of $300 \mathrm{mg} / \mathrm{l}$, and it

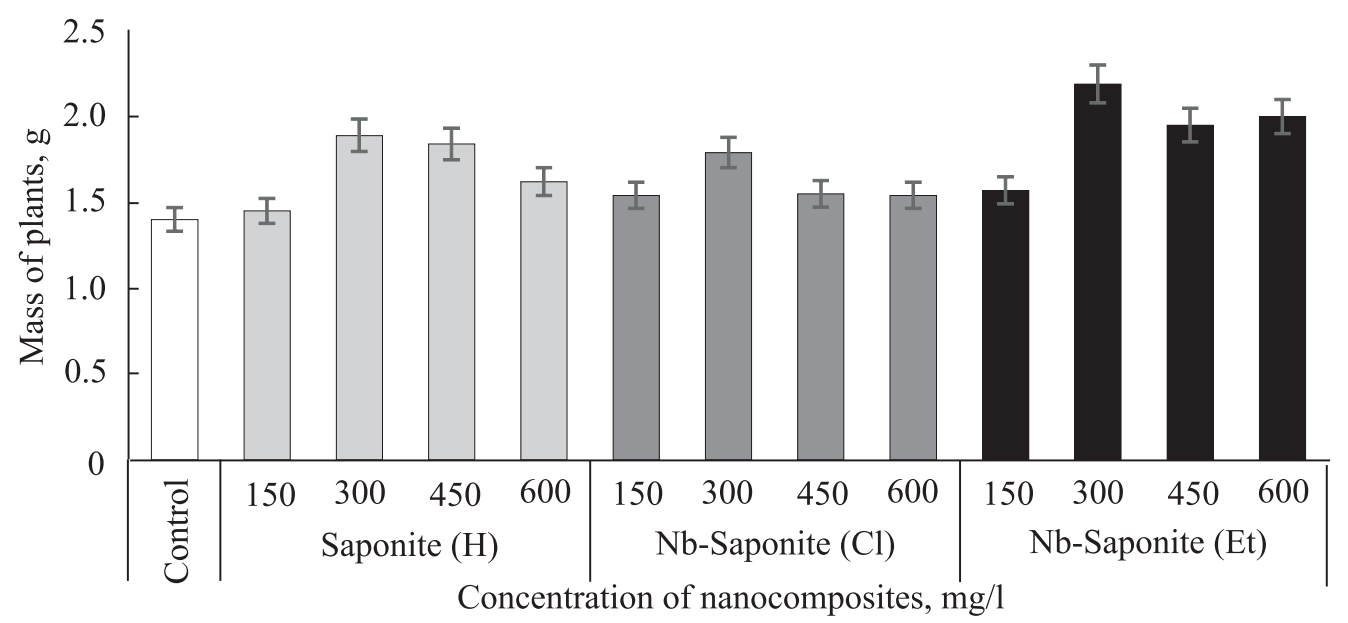

Fig. 4. The impact of nanocomposites on mass indices of corn plants 


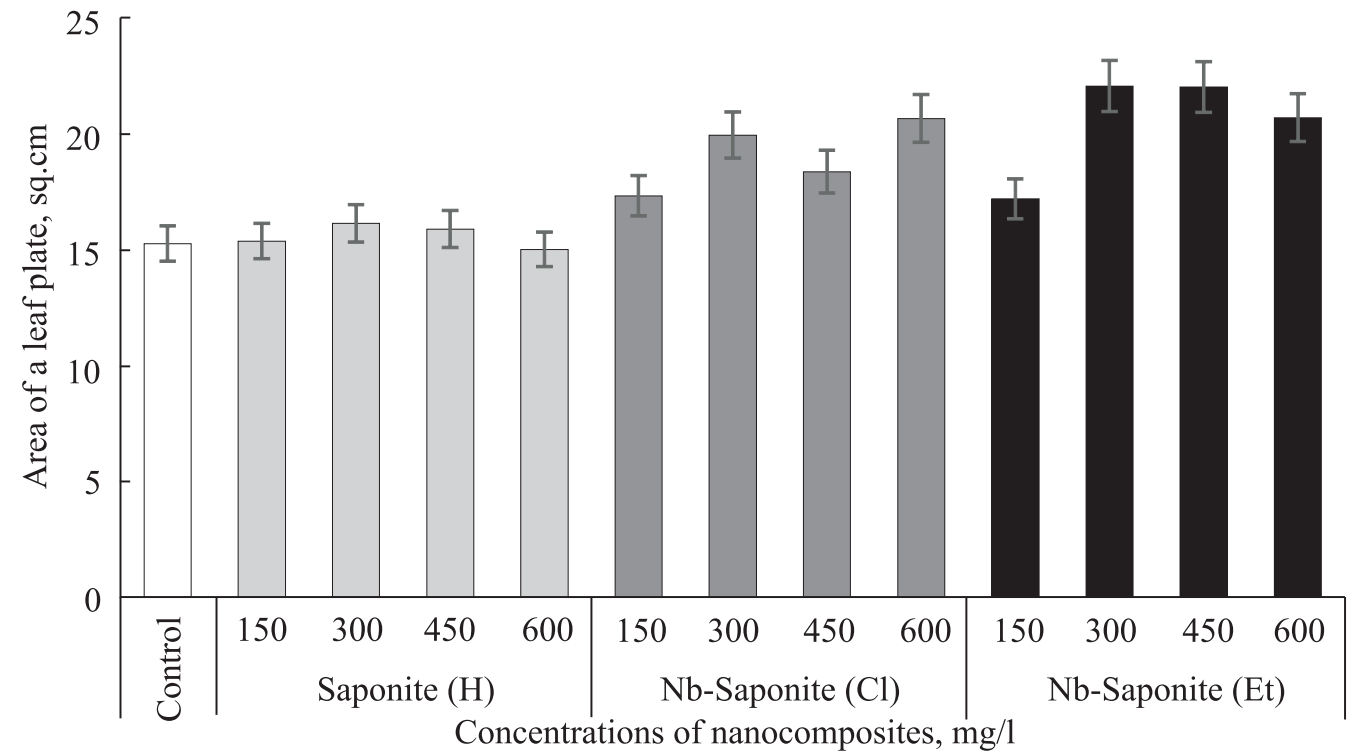

Fig. 5. The impact of nanocomposites on the area of a corn leaf plate

was 2.03 and $2.11 \mathrm{mg} / \mathrm{g}$ of the mass of raw substance, whereas in the control variant this index was $1.42 \mathrm{mg} / \mathrm{g}$.

A high content of chlorophyll $b$ was observed at the impact of nanocomposites based on Nb-Saponite (Et) in the concentration of $300 \mathrm{mg} / \mathrm{l}$ and $\mathrm{Nb}$-Saponite $(\mathrm{Cl})$ in the concentration of $600 \mathrm{mg} / \mathrm{l}$, it was $0.29 \mathrm{mg} / \mathrm{g}$ and $0.29 \mathrm{mg} / \mathrm{g}$, whereas in the control it was $0.23 \mathrm{mg} / \mathrm{g}$ (Table 5).

There was a noted increase in the sum of chlorophylls $(a+b)$ in variants of plants, whose seeds were previously treated with nanocomposites $\mathrm{Nb}$-Sapo- nite $(\mathrm{Cl})$ and $\mathrm{Nb}$-Saponite $(\mathrm{Et})$ in the concentration of $300 \mathrm{mg} / 1$ by 41.2 and $40.6 \%$ respectively compared to the control.

A photosynthetic apparatus is very sensitive to stress factors, the determination of the impact of different factors on the condition of plants requires application of express and informative methods which would allow conducting analyses both in laboratory and field conditions with minimal disruption of the integrity of the investigated objects. These methods include the method of fluorescence induction of chlorophyll, which is

Table 4. The mass indices of aboveground and underground parts of corn plants of hybrid Kharkivskyi $340 \mathrm{MV}$ in the phase of three leaves at the action of nanocomposites

\begin{tabular}{l|c|c|c}
\hline \multicolumn{1}{c|}{ Variants } & $\begin{array}{c}\text { Concentration in aqueous } \\
\text { medium, mg/l }\end{array}$ & $\begin{array}{c}\text { Mass of the aboveground } \\
\text { part, } g\end{array}$ & $\begin{array}{c}\text { Mass of the underground } \\
\text { part, } \mathrm{g}\end{array}$ \\
\hline Control & - & $0.8 \pm 0.06$ & $0.60 \pm 0.14$ \\
Nanocomposite Saponite (H) & 150 & $0.83 \pm 0.06$ & $0.62 \pm 0.05$ \\
& 300 & $1.16 \pm 0.17$ & $0.73 \pm 0.12$ \\
& 450 & $1.08 \pm 0.15$ & $0.76 \pm 0.11$ \\
Nanocomposite Nb-Saponite (Cl) & 600 & $0.94 \pm 0.10$ & $0.68 \pm 0.26$ \\
& 150 & $0.87 \pm 0.18$ & $0.67 \pm 0.08$ \\
& 300 & $1.03 \pm 0.12$ & $0.76 \pm 0.10$ \\
Nanocomposite Nb-Saponite (Et) & 450 & $0.81 \pm 0.12$ & $0.74 \pm 0.18$ \\
& 600 & $0.82 \pm 0.26$ & $0.72 \pm 0.05$ \\
& 150 & $0.86 \pm 0.16$ & $0.71 \pm 0.14$ \\
& 300 & $1.26 \pm 0.13$ & $0.93 \pm 0.05$ \\
& 450 & $1.08 \pm 0.09$ & $0.87 \pm 0.12$ \\
\hline
\end{tabular}




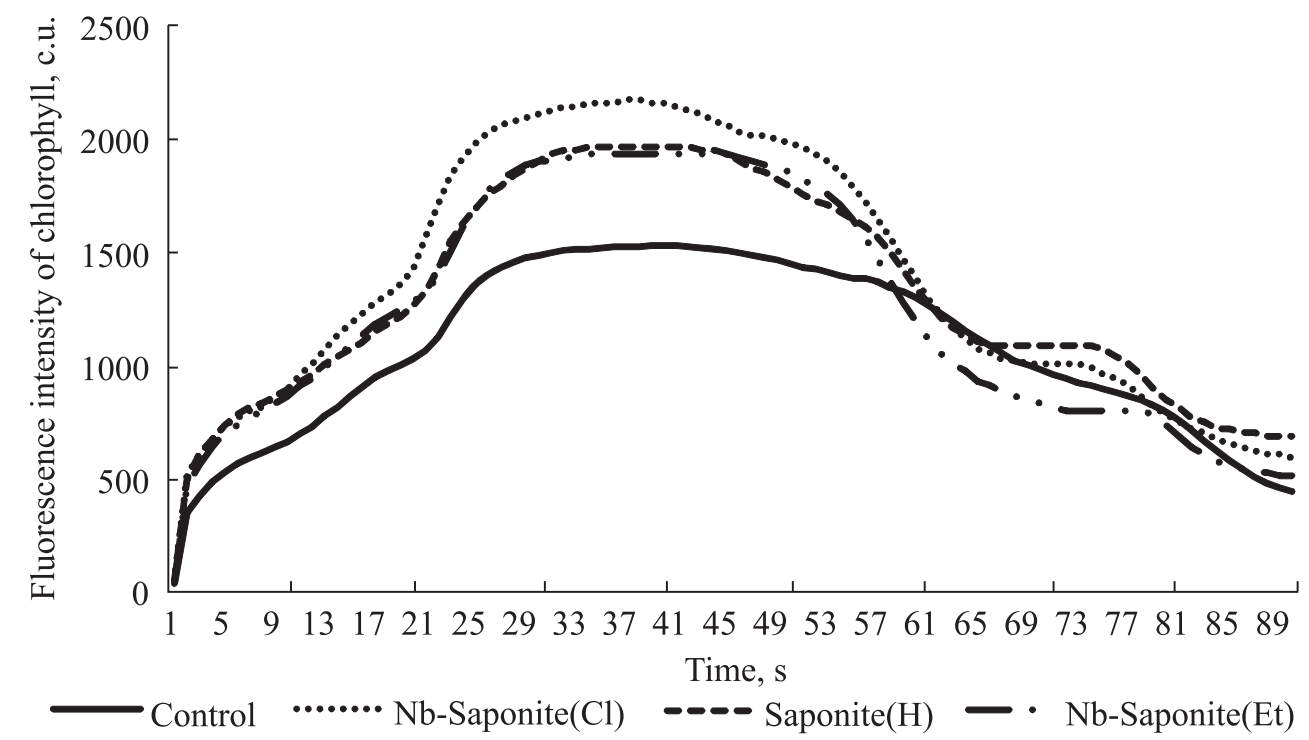

Fig. 6. The induction curves of fluorescence on corn chlorophyll at the action of nanocomposites

widely used in modern studies of photosynthetic processes [33-35].

The kinetics of changes in the curves of fluorescence induction of chlorophyll was determined by a portable device, a fluorimeter «Floratest», developed by the State scientific-engineering center of microelectronics at the Institute of Cybernetics named after V.M. Hlushkov (Ukraine).

The fluorescence induction of chlorophyll was measured in corn plants in the phase of three leaves on identical levels (Fig. 6), the plants, whose seeds were previously treated with water, were used as the control, the experimental samples were found in plants, whose seeds were treated with nanocomposites in the concentrations of $300 \mathrm{mg} / \mathrm{l}$, as this concentration increased sowing qualities of seeds and growth indices of plants.

The index of background fluorescence $\left(\mathrm{F}_{0}\right)$ characterizes the amount of inactive chlorophyll, which does not have any functional relation with the reaction centers i.e. it serves as the initial level of FIC. It depends on the

Table 5. The impact of nanocomposites on the content of chlorophylls in the leaves of hybrid corn Kharkivskyi 340 MV

\begin{tabular}{|c|c|c|c|}
\hline \multirow{2}{*}{ Variants } & \multirow{2}{*}{$\begin{array}{l}\text { Concentration in aqueous } \\
\text { medium, } \mathrm{mg} / \mathrm{l}\end{array}$} & \multicolumn{2}{|c|}{ Content of chlorophylls, $\mathrm{mg} / \mathrm{g}$ of mass of raw material } \\
\hline & & $\mathrm{C} \cdot a$ & $\mathrm{C} \cdot b$ \\
\hline Control & - & $1.42 \pm 0.07$ & $0.23 \pm 0.01$ \\
\hline \multirow[t]{4}{*}{ Nanocomposite Saponite $(\mathrm{H})$} & 150 & $1.91 \pm 0.08$ & $0.27 \pm 0.01$ \\
\hline & 300 & $1.63 \pm 0.06$ & $0.23 \pm 0.02$ \\
\hline & 450 & $1.64 \pm 0.07$ & $0.24 \pm 0.01$ \\
\hline & 600 & $1.38 \pm 0.06$ & $0.20 \pm 0.01$ \\
\hline \multirow[t]{4}{*}{ Nanocomposite $\mathrm{Nb}$-Saponite $(\mathrm{Cl})$} & 150 & $1.52 \pm 0.07$ & $0.23 \pm 0.03$ \\
\hline & 300 & $2.11 \pm 0.07$ & $0.22 \pm 0.01$ \\
\hline & 450 & $1.72 \pm 0.11$ & $0.28 \pm 0.02$ \\
\hline & 600 & $1.96 \pm 0.07$ & $0.29 \pm 0.02$ \\
\hline \multirow[t]{4}{*}{ Nanocomposite Nb-Saponite (Et) } & 150 & $1.52 \pm 0.06$ & $0.21 \pm 0.01$ \\
\hline & 300 & $2.03 \pm 0.08$ & $0.29 \pm 0.03$ \\
\hline & 450 & $1.79 \pm 0.10$ & $0.25 \pm 0.01$ \\
\hline & 600 & $1.86 \pm 0.05$ & $0.22 \pm 0.01$ \\
\hline
\end{tabular}

Note. $\mathrm{C} \cdot a$ - concentration of chlorophyll $a(\mathrm{mg} / \mathrm{g}$ of the mass of raw material); $\mathrm{C} \cdot b-$ concentration of chlorophyll $b$ (mg/g of mass of raw material). 


\section{ESTIMATION OF THE EFFICIENCY OF APPLYING NANOCOMPOSITES}

Table 6. The impact of nanocomposites on the indices of fluorescence induction of chlorophyll in corn plants of hybrid Kharkivskyi $340 \mathrm{MV}$

\begin{tabular}{c|c|c|c|c}
\hline \multirow{2}{*}{ Index } & \multicolumn{4}{|c}{ Variants } \\
\cline { 2 - 5 } & Control & $\begin{array}{c}\text { Nanocomposite } \\
\text { Saponite }(\mathrm{H})\end{array}$ & $\begin{array}{c}\text { Nanocomposite Nb- } \\
\text { Saponite }(\mathrm{Cl})\end{array}$ & $\begin{array}{c}\text { Nanocomposite Nb- } \\
\text { Saponite }(\mathrm{Et})\end{array}$ \\
\hline $\mathrm{F}_{0}$ & $347 \pm 17.21$ & $496 \pm 22.34$ & $512 \pm 23.09$ & $464 \pm 21.23$ \\
$\mathrm{~F}_{\mathrm{pl}}$ & $731 \pm 32.55$ & $960 \pm 41.12$ & $1008 \pm 49.14$ & $944 \pm 46.78$ \\
$\mathrm{dF}_{\mathrm{pl}}$ & $384 \pm 18.24$ & $464 \pm 19.67$ & $496 \pm 21.80$ & $480 \pm 25.36$ \\
$\mathrm{~F}_{\max }$ & $1531 \pm 74.55$ & $1968 \pm 87.12$ & $2176 \pm 98.88$ & $1936 \pm 96.05$ \\
$\mathrm{~F}_{\mathrm{st}}$ & $442.7 \pm 19.14$ & $688 \pm 32.43$ & $592 \pm 27.98$ & $512 \pm 21.98$ \\
$\mathrm{~F}_{\mathrm{v}}$ & $1184 \pm 53.45$ & $1472 \pm 68.32$ & $1664 \pm 79.34$ & $1472 \pm 71.65$ \\
$\mathrm{~F}_{\mathrm{v}} / \mathrm{F}_{\max }$ & $0.77 \pm 0.03$ & $0.75 \pm 0.02$ & $0.76 \pm 0.03$ & $0.76 \pm 0.04$ \\
$\left(\mathrm{~F}_{\max }-\mathrm{F}_{\mathrm{st}} / \mathrm{F}_{\mathrm{st}}\right.$ & $2.46 \pm 0.12$ & $1.86 \pm 0.07$ & $2.68 \pm 0.10$ & $2.78 \pm 0.14$ \\
\hline
\end{tabular}

Note. $\mathrm{F}_{0}$ - index of background chlorophyll fluorescence, $\mathrm{F}_{\mathrm{pl}}-$ level of fluorescence plateau, $\mathrm{F}_{\max }-$ maximal value of fluorescence, $\mathrm{F}_{\mathrm{v}}$ - variable value of fluorescence, $\mathrm{F}_{\mathrm{st}}$ - stationary level of fluorescence.

losses of excitation energy during the migration with pigment matrix. The index $\mathrm{F}_{0}$ of corn plants, treated with nanocomposites, was in the range from 464 c.u. to 512 c.u. and it was higher than the index in control plants, which was 347 c.u. (Table 6). It demonstrated a higher number of antenna chlorophylls in the investigated samples compared to the control, such data may be explained by a structural change in pigment complex of corn plants at the action of nanocomposites.

At the action of nanocomposites Saponite $(\mathrm{H}), \mathrm{Nb}-$ Saponite $(\mathrm{Cl})$ and $\mathrm{Nb}$-Saponite (Et) the index $\mathrm{d} \mathrm{F}_{\mathrm{pl}}$ increased by $20.8,29.2$ and $25 \%$ on average respectively compared to the control. These data demonstrate the increase in the value of fluorescence from $\mathrm{F}_{0}$ to $\mathrm{F}_{\mathrm{pl}}$ in plants at the action of nanomaterials.

The stationary level of fluorescence is characterized by a dynamic equilibrium between the processes, conditioning the increase in fluorescence, and the proces-ses, causing its decrease. At the action of nanocompo-sites in plants, the index $\mathrm{F}_{\mathrm{st}}$ was $35 \%$ higher on average compared to the control.

Index $\mathrm{F}_{\text {max }}$ indicates the highest level of fluorescence, registered on the induction curve as its maximum. The highest value $\mathrm{F}_{\text {max }}$ was registered for plants, treated with nanocomposite $\mathrm{Nb}$-Saponite $(\mathrm{Cl})$, and it was 2176 c.u.

The variability of fluorescence $\left(F_{v}\right)$ is calculated as the difference between indices $\mathrm{F}_{\max }$ and $\mathrm{F}_{\mathrm{o}}$ and is a physiological index, reflecting the action of environmental and experimental factors of a plant. At the action of nanocomposites Saponite $(\mathrm{H}), \mathrm{Nb}$-Saponite (Cl) and $\mathrm{Nb}$-Saponite (Et), this index in plants was
1472,1664 and 1472 c.u., whereas in the control it was 1184 c.u. These data confirm the impact of nanomaterials on physiological processes in plants.

Indices $\mathrm{F}_{\mathrm{v}} / \mathrm{F}_{\max }$ depend on the efficiency of photochemical reactions of a photosystem (PS) 2 [22]. In dark-adapted plants this coefficient reflects the potential quantum efficiency of PS 2, which is used as an indicator of photosynthesis performance, the optimal value for which for most species of plants in conditions of saturated intensity of exciting light does not exceed the value of 0.83 . According to the data of studies, the index $\mathrm{F}_{\mathrm{v}} / \mathrm{F}_{\max }$ in the control and experimental plants was in the range of $0.75-0.77$ c.u., which proves a normal course of photosynthesis both in control and experimental plants.

The efficiency of photochemical energy transformation in PS 2 was calculated by the formula $\left(\mathrm{F}_{\max }-\mathrm{F}_{\mathrm{st}}\right) / \mathrm{F}_{\mathrm{st}}$, which characterizes the rate of linear transportation of electrons. It is an integral index of photosynthesis, which changed in the investigated plants from 1.86 to $2.78 \mathrm{c}$.u.

\section{CONCLUSIONS}

The study on the impact of nanocomposites, based on saponite, on biometric and physiological indices of hybrid corn Kharkivskyi 340 MV allows a conclusion on the stimulating action of newly synthesized nanocomposites regarding growth processes in corn plants.

Presowing treatment of hybrid corn seeds with nanocomposite solutions increased the energy of germination, sprouting and length of plants seedlings. At the 


\section{SAVCHUK et al.}

impact of nanocomposite $\mathrm{Nb}$-Saponite (Et) in the concentration of $300 \mathrm{mg} / 1$ the energy of germination increased by $10.6 \%$, seed germination was $100 \%$, the lengths of a stem part of seedlings increased twice, and the root part increased by $30 \%$.

Newly synthesized nanocomposites stimulated the growth of hybrid corn plants in the phase of three leaves. After presowing treatment of seeds with nanocomposites the height of a plant stem exceeded the control by $26 \%$ on average, the length of the root system increased twice on average, the mass and area of a leaf plate of plants increased. It was noted that the impact of nanocomposites led to the increase in the number and length of roots, stimulated the development of additional roots, and the formation of root fibrilla.

The spectrophotometric analysis demonstrated an increase in the sum of chlorophylls $(a+b)$ in the leaves of plants, whose seeds had previously been treated with nanocomposites. A detailed analysis of Kautsky curve indices in the control and experimental plants demonstrated that newly-synthesized nanocomposites did not cause any disruptions in the processes of fluorescence induction of chlorophyll.

\section{Оцінка ефективності застосування нанокомпозитів як екологічно-безпечних нанодобрив для стимулювання біометричних показників сільськогосподарських рослин}

М. В. Савчук ${ }^{1}$, М. Ф. Стародуб ${ }^{1}$, C. Bisio ${ }^{2}$, M. Guidotti ${ }^{3}$, M. М. Лісовий ${ }^{1}$

e-mail: TaranMaruna@gmail.com,nfstarodub@gmail.com, matteo@istm.cnr.it, chiara.bisio@uniupo.it, lisova106@ukr.net

${ }^{1}$ Національний університет біоресурсів і природокористування України, Україна, 03041, м. Київ, вул. Героїв Оборони, 15

${ }^{2}$ University of Eastern Piedmont «A. Avogadro", Alessandria, Italy

${ }^{3}$ CNR-Institute of Molecular Sciences and Technology, Milano, Italy

Мета. Оцінити можливостівикористання нанокомпозитів на основі сапоніту для підвищення біометричних показників гібрида кукурудзи Харківський 340 МВ. Методи. Лабораторні (метод сканувальної електронної мікроскопії, метод індукції флуорисценції хлорофілу, спектрофотометричний метод визначення кількості зелених пігментів, методи визначення біометричних показників рослин), статистичні. Результати. У даній статті представлено результати дослідження впливу нанокомпозитів на біометричні показники гібрида кукурудзи Харківський 340 МВ. Встановлено, що передпосівна обробка насіння кукурудзи водними розчинами нанокомпозитів на основі сапоніту у концентрації 300 мг/л стимулювала ростові показники рослин. Передпосівне замочування насіння в розчинах нанокомпозитів підвищувало енергію проростання, схожість і довжину проростків гібрида кукурудзи. За дії нанокомпозиту $\mathrm{Nb}$-Saponite (Et) в концентрації 300 мг/л відбувається збільшення енергії проростання на 10,6 \%, довжини стеблової частини - у 2 рази, кореневої системи - на 30,3 \% та лабораторна схожість насіння становить $100 \%$. Висота стебла рослин кукурудзи у фазі трьох листків за передпосівної обробки насіння нанокомпозитами Saponite $(\mathrm{H})$, Nb-Saponite $(\mathrm{Cl})$ i $\mathrm{Nb}$ Saponite (Et) у концентрації 300 мг/л перевищувала контроль на 31,7, 26,2 та 42,7 \%, водночас довжина кореневої системи зростала у 2 рази. За дії Saponite $(\mathrm{H})$ i Nb-Saponite $(\mathrm{Cl})$ збільшувалась кількість і довжина головних коренів кукурудзи, а Nb-Saponite (Et) стимулював розвиток додаткових коренів та формування кореневих волосків. Передпосівна обробка насіння кукурудзи розчинами нанокомпозитів Saponite $(\mathrm{H}), \mathrm{Nb}-$ Saponite (Cl), Nb-Saponite (Et) в концентрації 300 мг/л сприяла збільшенню вегетативної маси на 35, 27,9 та 56,4 \%, ніж у контролі. Площа листкової пластинки рослин за впливу нанокомпозитів збільшувалась в середньому на 20,4 \%. Було виявлено зростання суми хлорофілів $(\mathrm{a}+\mathrm{b})$ у рослин, насіння яких попередньо оброблене нанокомпозитами $\mathrm{Nb}$-Saponite $(\mathrm{Cl})$ та $\mathrm{Nb}$ Saponite (Et) в концентрації 300 мг/л на 41,2 та 40,6 \% відповідно до контролю. Висновки. Застосування нанокомпозитів на основі сапоніту в концентрації 300 мг/л для передпосівної обробки насіння кукурудзи гібриду Харківський 340 MB, спричиняє активацію ростових показників та покращує процес проходження фотосинтезу.

Ключові слова: нанокомпозити, кукурудза, насіння, ростові процеси, фізіологічні параметри, стебло, коренева система.

\section{Оценка эффективности применения нанокомпозитов как экологически безопасных наноудобрений для стимулирования биометрических показателей сельскохозяйственных растений}

М. В. Савчук ${ }^{1}$, Н. Ф. Стародуб ${ }^{1}$, C. Bisio ${ }^{2}$, M. Guidotti ${ }^{3}$, Н. М. Лесовой ${ }^{1}$

e-mail: TaranMaruna@gmail.com,nfstarodub@gmail.com, matteo@istm.cnr.it, chiara.bisio@uniupo.it, lisova106@ukr.net

${ }^{1}$ Национальный университет биоресурсов и природопользования Украины

03041, г. Киев, ул. Героев Обороны, 15

${ }^{2}$ University of Eastern Piedmont «A. Avogadro», Alessandria, Italy

${ }^{3}$ CNR-Institute of Molecular Sciences and Technology, Milano, Italy 


\section{ESTIMATION OF THE EFFICIENCY OF APPLYING NANOCOMPOSITES}

Цель. Оценить возможности использование нанокомпозитов на основе сапонита для повышения биометрических показателей гибрида кукурузы Харьковский 340 МВ. Методы. Лабораторные (метод сканирующей электронной микроскопии, метод индукции флюорисценции хлорофилла, спектрофотометрический метод определения количества зеленых пигментов, методы определения биометрических показателей растений), статистические. Результаты. В данной статье представлены результаты исследования влияния нанокомпозитов на биометрические показатели гибрида кукурузы Харьковский 340 МВ. Установлено, что предпосевная обработка семян кукурузы водными растворами нанокомпозитов на основе сапонита в концентрации 300 мг/л стимулировала ростовые показатели растений. Предпосевное замачивание семян в растворах нанокомпозитов повышало энергию прорастания, всхожесть и длину проростков гибрида кукурузы. За действия нанокомпозита Nb-Saponite (Et) в концентрации 300 мг/л происходит увеличение энергии прорастания на 10,6 \%, длины стеблевой части - в 2 раза, корневой системы - на 30,3 \% и лабораторная всхожесть семян составляет $100 \%$. Высота стебля растений кукурузы в фазе трех листьев после предпосевной обработки семян нанокомпозитами Saponite (H), $\mathrm{Nb}-$ Saponite (Cl) и Nb-Saponite (Et) в концентрации 300 мг/л превышала контроль на 31,7, 26,2 и 42, 7 \%, в то же время длина корневой системы возрастала в 2 раза. За действия Saponite $(\mathrm{H})$ и $\mathrm{Nb}$-Saponite $(\mathrm{Cl})$ увеличивалось количество и длина главных корней кукурузы, а $\mathrm{Nb}$-Saponite (Et) стимулировал развитие дополнительных корней и формирования корневых волосков. Предпосевная обработка семян кукурузы растворами нанокомпозитов Saponite $(\mathrm{H}), \mathrm{Nb}$-Saponite $(\mathrm{Cl})$, Nb-Saponite (Et) в концентрации 300 мг/л способствовала увеличению вегетативной массы на 35, 27,9 и $56,4 \%$, чем в контроле. Площадь листовой пластинки растений при воздействии нанокомпозитов увеличивалась в среднем на 20,4 \%. Отмечен рост суммы хлорофиллов $(\mathrm{a}+\mathrm{b})$ у растений, семена которых предварительно обработанные нанокомпозитами $\mathrm{Nb}$-Saponite (Cl) и Nb-Saponite (Et) в концентрации 300 мг/л на 41,2 и 40,6 \% соответственно к контролю. Выводы. Применение нанокомпозитов на основе сапонита в концентрации 300 мг/л для предпосевной обработки семян кукурузы гибрида Харьковский 340 МВ, вызывает активацию ростовых показателей и улучшает процесс прохождения фотосинтеза.

Ключевые слова: нанокомпозиты, кукуруза, семена, ростовые процессы, физиологические параметры, стебель, корневая система.

\section{REFERENCES}

1. Taran NYu, Batsmanova LM, Lopatko KG, Kalenska SM. The technology of environmentally safe use of na- noparticles in adaptive crop production. Fizyka zhyvoho. 2011;19(2):4-58. (in Ukrainian)

2. Taran NYu, Batsmanova LM, Lopatko KG, Meleshko A.O., Konotop YeO. Influence of non-ionic colloid solution of nanoparticles of biogenic metals on metal content in plants tissues. Fizyka zhyvoho. 2011;19(2):9-11 (in Ukrainian).

3. Gorokhovsky AV, Arkhipov NV, Simakov VV. Composite nanomaterials: [manual for students of all specialties]. Saratov.SSTU. 2010;1:68 (in Russian).

4. Ezhkov VO, Bikkinina LM-Kh, Polivanov MA. Influ-ence of nanostructured water-zeolite suspension on buckwheat productivity. Bulletin of Kazan technological University. 2013;16(19):241-5 (in Russian).

5. Racuciu M, Creanga D. Cytogenetic changes induced by beta-cyclodextrin coated tanoparticles in plant seeds. Romanian J. Phys. 2009;54:125-31.

6. Vyatchina OF, Zhdanova $G O$. Evaluation of the reduction in toxicity of heavy metals by humates using Saccharomyces cerevisiae. Sofia.Bel Grad-BG. 2011;1:64-8 (in Russian).

7. Gonchar LM. Action of colloidal solution of copper and zinc on seed germination of oats. Visnyk Poltavskoyi Derzhavnoyi agrarnoyi akademiyi. 2016;(4):45-8 (in Ukrainian).

8. Kalenska S, Lopatko $K$, Novictska $N$. Efficiency of biogenic metals and bio-active drugs in soybean. Naukovi dopovidi NUBiP. 2011;5(27). http://nd.nubip.edu. ua/2011 5/11ksm.pdf (in Ukrainian).

9. Panyuta $O$, Belava $V$, Fomaidi S, Kalinichenko $O$, Taran $N$. Influence of processing of wheat seeds by metal nanoparticles on defense reactions in wheat seedlings under eyespot causal agent. Visnyk Kyyivskogo nacionalnogo universytetu im. Tarasa Shevchenka. 2014;1(17):4851 (in Ukrainian).

10. Sytar O, Novicka N, Taran N, Kalenska S, Ganchurin V. Nanotechnology in modern agriculture. Fizyka zhyvoho. 2010;18(3):113-6 (in Ukrainian).

11. Fetisov GV. Synchronous radiation. Methods for studying the structure of substances. Moscow. Fizmatlit. 2007; 1:672 (in Russian).

12. Vinogradov D. Herbicides and their mixtures on crops of spring rapeseed. Hlavnyi ahronom. 2010;10:21-3 (in Russian).

13. Sozer N, Kokini JL. Nanotechnology and its applications in the food sector. Trends Biotechnol. 2009;27:82-9.

14. Savchuk MV, Starodub MF. Determination of the cytotoxicity of new nanocomposites based on saponite. Scientific Bulletin of UNFU. 2017;27(4):137-9. doi: $10.15421 / 40270430$ (in Ukrainian).

15. Savchuk MV. Assessment of phytotoxicity of $\mathrm{Nb}$-containing nano-composites on the basis of saponites with the use of cress-salad (Lepidium sativum L.). Visnyk ahrarnoi nauky. 2017;6:74-6 (in Ukrainian).

16. Guidotti M, Psaro R, Ravasio N, Sgobba M, Carniato F, 


\section{HOSPODARENKO et al.}

Bisio $C$, Gatti G, Marchese L. An efficient ring opening reaction of methyl epoxystearate promoted by synthetic acid saponite clays. Green Chem. 2009;11(8):1173-8.

17. Kyrpa MYa, Scotar, SO, Bazileva YuS, Lupitko OI. Sowing characteristics of cereal seeds and methodology of their determination. Plant breeding and seed production 2016;(110):171-9. Doi: https://doi.org/10.30835/24137510.2016.87625 (in Ukrainian).

18. Kyrpa MYa, Paschenko NO. Methods of determining the similarity of high quality corn seeds. Biuleten Instytutu zernovoho hospodarstva UAAN. 2003;20:60-62 (in Ukrainian).

19. Moiseychenko F, Trifonova M, Zaveryukha A, Eshchen$k o V$. Fundamentals of scientific research in agronomy. Moscow: Kolos. 1996;336 (in Russian).

20. Gritsaenko Z, Grytsaenko A, Karpenko V. Methods of biological and agrochemical researches of plants and soils. K.: JSC «Nichlava». 2003;20 (in Ukrainian).

21. Musienko M, Parshikova T, Slavniy P. Spectrophotometric methods in the practice of physiology, biochemistry and ecology of plants. Kyiv: Fitosotsiotsentr. 2001;200 (in Ukrainian).

22. Brayon A, Korneev D, Snegur A, Kitaev O. Instrumental study photosynthetic apparatus using chlorophyll fluorescence induction [method. instructions for students. Biol. Ft.]. Kyiv: Kyivskyi universytet, 2000;15 (in Ukrainian).

23. Korsunsky V, Snegur A. Instruction to the device «Floratete FT-1». Rost. 1997;11 (in Ukrainian).

24. Kovalyshyn I, Pinchuk A, Taran M, Shvets R. Chlorophyll fluorescence induction of the genus Clematis L. representatives leaves in Kyiv conditions. Naukovyi visnyk NUBiP Ukrainy. Seriia: Lisivnytstvo ta dekoratyvne sadivnytstvo. 2016;238:176-84 (in Ukrainian).

25. Omeniuk NY, Savchuk MV, Kriuchkova LO, Antonenko OF, Starodub MF. Nb-contained nanocomposites impact on seeds mycoflora and growth parameters of maize seedlings. Naukovyi visnyk NUBiP Ukrainy. Seriia: Ahronomiia. 2017;269:251-9 (in Ukrainian).
26. Kyrpa MYa, Paschenko NO, Sturko MO. Method of determining the suitability of corn seeds for sowing. Ahrarna nauka vyrobnytstvu: nauk.-inform. biul. zavershenykh nauk. rozrobok. Kyiv. 2013;4:20 (in Ukrainian).

27. Kyrpa MYa, Sturko MO. The homogeneity of corn seeds and methods of its determination. Plant breeding and seed production. 2012;102:135-43 (in Ukrainian).

28. Chikov VI. Photosynthesis and plant productivity. Sorosovskyi obrazovatelnyi zhurnal. 1997;(12):23-7 (in Russian).

29. Kalenska SM, Scherbakova EN, Gonchar LM. Assimilative activities crops of chickpea depending on the varietal features and preseeding seed treatment. Visnyk Sumskoho natsionalnoho ahrarnoho universytetu. Seriia «Ahronomiia i biolohiia». 2014;9(28):110-3 (in Ukrainian).

30. Nichiporovich $A A$. Photosynthetic activity of plants and ways of increasing their productivity. Theoretical bases of photosynthetic productivity. M: Nauka. 1972:511-27 (in Russian).

31. Rudnyk-Ivashchenko OI. Content of chloroplasts in leaves of plants millet in photosynthesis process // Naukovi dopovidi NUBiP Ukrainy.2010;(3):19 c (in Ukrainian).

32. Scheer H. Chlorophylls and carotenoids. Encyclopedia of Biological Chemistry 2004; 430-37.

33. Karapetyan NV, Bukhov NG. Variable fluorescence of chlorophyll as an indicator of the physiological state of plants. Plant physiology.1986;33(5):1013-26 (in Ukrainian).

34. Korneev DYu, Kochubei SM. Investigation of QV-reducing complexes of photosystem 2 by induction of fluorescence of chlorophyll. Physiology and biochemistry of cultivated plants. 2000;32(1):20-4 (in Ukrainian).

35. Tarnovskyi MG, Yankovskyi YaYu. Optical methods of analysis of the physiological state of plants for the tasks of agriculture and ecological monitoring. Optyko-elektronni informatsiino-enerhetychni tekhnolohii: mizhnar. nauk.-tekhn. zhurnal. 2012;23(1):127-30 (in Ukrainian). 